\title{
Principles of Christian Law - Erratum
}

\author{
Mark Hill QC \\ Centre for Law and Religion, Cardiff University; Faculty of Theology, University of Pretoria \\ Dickson Poon School of Law, King's College London; Notre Dame University Law School, \\ Sydney
}

Norman Doe

Professor and Director, Centre for Law and Religion, Cardiff University

doi:10.1017/So956618X17000035. Published online by Cambridge University Press, 2 May 2017

In the above publication ${ }^{1}$, a note from the editing stage was printed in footnote 3 . This been removed from the published article. The publisher apologises to the authors and readers for this error.

1 Hill, M., \& Doe, N. (2017). Principles of Christian Law. Ecclesiastical Law Journal, 19(2), $138-155$. doi:10.1017/So956618X17000035 